\title{
Interaction between Organic Production and Genetically Modified Organisms: European Regulatory Framework and Positions to Unification of National Legislation of Ukraine
}

\author{
Oleksii Piddubnyi ${ }^{1}$, Daria Piddubna ${ }^{2}$ and Nataliya Obiiukh ${ }^{3}$
}

\begin{abstract}
The determined global direction towards the development of organic farming has come to gain its support in each country. Ukraine is no exception here as the country which has chosen for itself the course on European integration and therefore it has taken on certain responsibilities. Among these issues it is possible to determine the ways to harmonization of national legislation. That process should be taken through careful study of European legal regulation as well as the practice in its application and the current positive or negative aspects, gaps, etc. Such a systematic approach will provide the opportunity to develop new laws to ammend the current legal acts that will maximally regulate the relevant social relations. The reason for the chosen direction of scientific research is that it is often dificult, and sometimes impossible, to combine organic production and activities with the use of genetically modified organisms. The research paper focuses on detailed characteristic of European legislation in the sphere of genetically modified organisms and analysing the general EU legal acts in the sphere of organic production. There are established the present provitions of national legislation and it is determined the structure of actions in order to support the development and spreading of organic farming in Ukraine.
\end{abstract}

Keywords: organic production, organic farming, genetically modified organisms, unification, national legislation, European legal framework, scietific doctrine

\section{Introduction}

The geographic location of Ukraine, its natural resources, human potential and many other components make it unique on the world map. With this course of European integration as well as the Euro-Atlantic orientation and by acceding to systematic actions to prevent anthropogenic climate change, the respective obligation for Ukraine has emerged. That obligation is to carry out certain actions for a series of vectors which are aimed at system and complex changes. Such vectors reach a broad range of directions depending on the particular subject of consideration. In particular, in considering a legal approach to the problem, it is necessary to notice the need for a comprehensive analysis of international legal acts and documents accompanying the appropriate type of organic farming including the preconditions for their adoption, the

${ }^{1}$ Doctor of Law, associate professor, head of the Department of Civil and Commercial Law of the National University of Life and Environmental Sciences of Ukraine.

${ }^{2}$ Ph.D. in Law, head of the Department of Civil Law Disciplines of Donetsk Law Institute of the Ministry of Internal Affairs of Ukraine.

${ }^{3} \mathrm{Ph} . \mathrm{D}$. in Law, assistant professor of the Department of Civil Law Disciplines of Bila Tserkva National Agrarian University, Ukraine. 
current state and position of further improvement. Such study should become not the basis for the implementation of the similar legal acts in Ukraine, but as a sure step in the analysis of such positions taking into account national characteristics, territoriality, public interests, as well as in order to identify further directions of the state's development regarding the protection of rights, freedoms and the interests of every citizen.

Certain actions by the executive authorities are already known for the country. Thus, the Cabinet of Ministers of Ukraine on December 07, 2016 approved the Concept of State Climate Change Policy Implementation until 2030. The preamble of this Concept refers to the implementation of the provisions of the Paris Agreement, on which Ukraine is a full-fledged party.

It is especially important the position that regulates that "the international community recognized at the outset of the $21^{\text {st }}$ century that climate change is one of the key problems of the world development with potentially serious threats for the global economy and international security due to increased direct and indirect risks related to energy security, food and potable water supplies, and sustainable existence of ecosystems, and risks to human health and life" (Cabinet of Ministers of Ukraine, 2016).

To ensure climate stability, the United Nations Framework Convention on Climate Change, which contains the provisions that clearly set out positions for achieving sustainable economic growth and poverty eradication, should be mentioned, and its objective is "... to achieve, in accordance with the relevant provisions of the Convention, stabilization of greenhouse gas concentrations in the atmosphere at a level that would prevent dangerous anthropogenic interference with the climate system. Such a level should be achieved within a time frame sufficient to allow ecosystems to adapt naturally to climate change, to ensure that food production is not threatened and to enable economic development to proceed in a sustainable manner"(Verkhovna Rada of Ukraine, 1996).

This provision indicates the need for providing ecological farming, food security, health and human life, environmental protection, socio-economic stability and the country's development. This is due to a number of reasons. Firstly, in relation to the need to study and to ensure the uniform application of the law regulating organic farming with a distinction of legal regulation regarding all elements (components) of its implementation; secondly, taking into account the specificity of organic direction and spreading the use of genetically modified organisms, there is a need for the study of the regulatory framework in this field. However, thirdly, the food security and food quality problem concerns the human rights and freedoms, therefore, it is necessary to take into account international legal acts, as well as decisions of international courts, including decisions of the European Court of Human Rights. These three positions in the direction of ensuring food, ecological safety, as the elements of national security, are the key to the development of socio-economic and legal society of Ukraine in the international arena.

Besides the practical experience related to the use of genetically modified organisms and implementation of organic farming that has been taken into account, it must be noted of the theoretical work in these areas. It should be noted the Ukrainian and foreign scholars in the field of law, economics, sociology, philosophy, which exposed the issue of genetically modified organisms and organic production in their 
scientific works (Bezus R.M., 2014), (Berlach N.A., 2011), (Gregorich E.G., Beare M.H., McKim U.F., Skjemstad J.O., 2006), (Grabak N.H., 2012), (Kirchmann H., Bergstro L., Katterer T., Mattsson L., Gesslein S., 2007), (Meniv O.I., 2015), (Myrick C.A., Tomasso J.R., 2002), (Overkovskaya T.K., 2017); (Pavlyuchenko Yu.M., 2015), (Piddubnyi O.Yu., Piddubna D.S., 2017), (Urkevych V.Yu., 2014) and others. However, the works of these scientists can be characterized as a scientific doctrine from the standpoint that considers the issues of biotechnology, organic management in certain fragmentary characteristics of some elements. Guided by the European integration direction of Ukraine and the emergence of new social relations, nowadays there is a need for a broadened consideration of this direction precisely from the position of ensuring the further implementation of European legislation to the national one.

\section{International Legal Regulation of Genetically Modified Organisms as the Element that is of Unacceptable in Organic Production}

The Cartagena Protocol on Biosafety (2000), the WTO Agreement on the Application of Sanitary and Phytosanitary Measures (Verkhovna Rada of Ukraine, 1994), the Agreement on Technical Barriers to Trade (Verkhovna Rada of Ukraine, 1994) belong to the group of international acts, but they should not be confused with the normative acts that regulate the direct application of GMOs. Thus, the Cartagena Protocol on Biosafety provides for the use of the principle of "caution" and "precautionary measures" to ensure an adequate level of protection in the field of the safe transfer, handling and use of living modified organisms resulting from modern biotechnology that may have adverse effects on the conservation and sustainable use of biological diversity, taking also into account risks to human health, and specifically focusing on transboundary movements. Exporters of GMOs must report the competent national authorities on transboundary movements in advance. In turn, local authorities are required to inform about granting permits and export conditions for such organisms within 90 days.

Information on their movement is transmitted to the "Biosafety ClearingHouse", which serves as a mechanism for facilitating the exchange of information on GMOs and helping Member States better fulfill their obligations under the Protocol. This legal act contains the requirements for marking, transportation, evaluation and management of risks associated with GMOs transportation.

The Agreement on the Application of Sanitary and Phytosanitary Measures of 15 April 1994 provides that " no Member should be prevented from adopting or enforcing measures necessary to protect human, animal or plant life or health, subject to the requirement that these measures are not applied in a manner which would constitute a means of arbitrary or unjustifiable discrimination between Members where the same conditions prevail or a disguised restriction on international trade"(SPS Agreement, 1994). The established provisions are aimed at improving the health of humans, animals and the phytosanitary situation, taking into account the application of sanitary measures on the basis of a bilateral agreement or protocols; creation of a multilateral system of rules that regulate the development, adoption, and application of these measures in order to minimize their negative impact on trade; subject to the international standards, 
guidelines and recommendations. The use of the above-mentioned aspects should be based on the cooperation of organizations such as the Codex Alimentarius Commission, the International Bureau of Epizootics and also relevant organizations operating under the International Plant Protection Convention. At the same time, the Member-States are not obliged to change the appropriate level of protection of human, animal or plant life and health.

The Agreement on Technical Barriers to Trade is based on the Uruguay Round of Multilateral Trade Negotiations and aims to achieve the goals of the GATT 1994. The agreement contains the following important provisions:

- the technical regulations and standards, including packaging, marking and labeling requirements, and procedures for assessment of conformity should not create unnecessary barriers to international trade;

- no country should be prevented from taking measures necessary to ensure the quality of its exports, or for the protection of human, animal or plant life or health, of the environment, or for the prevention of deceptive practices, at the levels it considers appropriate, subject to the requirement that they are not applied in a manner which would constitute a means of arbitrary or unjustifiable discrimination between countries where the same conditions prevail or a disguised restriction on international trade.

Besides, no country should be prevented from taking measures that are necessary for the protection of its essential security interests.

The outlines of the distribution of legal acts are complemented by another structure that already exists in the world. That is why we can safely say about the current international legal regulation of the GMOs handling.

The efforts of the global community in the $21^{\text {st }}$ century are aimed at combating genetic pollution, invasions and terrorism (biological, ecological, food). At the same time, the international context regulates the relevant types of legal acts: "The World Charter for Nature" 1982 (The Verkhovna Rada of Ukraine, 1982), "The Note of the 21st Century" / Principle 15 of the Rio Declaration, adopted in 1992 at the United Nations Conference on Environment and Development (The Agenda for the $21^{\text {st }}$ century, 1992); Amman and Bangkok Resolutions, Codex Alimentarius, Cartagena Protocol on Biosafety to the Convention on Biological Diversity (Problems of international legal regulation of GMO treatment, 2019); Directive of the European Union (Directive 2001/18/EC, 2001), (Regulation (EC) No 1829/2003, 2003), (A moratorium on the further release of Genetically Modified Organisms (GMOs), 2019) and others.

Except for notified legislative acts, the dissemination and use of GMOs is regulated by the adoption of relevant decisions by European Commission. In particular, it is established to keep registers under the unified standard: methods for identification and detection, environmental monitoring, monitoring of the interaction of GMOs with the environment, human health effects, marking and post-market monitoring, emergency measures (Commission Decision of 23 February 2004, 2004). This Decision was adopted in order to comply with the provisions of EU Directive 1829/2003 regulating the use of food and feed containing or consisting of GMOs and should not adversely affect human and animal health, the environment. Labelling of foodstuffs and food ingredients should include objective information about food and feed products produced from GMOs 
(there is undertaken a single risk assessment and there is issued a single GMO's authorization).

Along with mentioned measures there are also national measures to prevent the uncontrolled dissemination of genetically modified products. Adopted in 1997, Regulation for New Foodstuffs (Regulation (EC) No 258/97, 1997) establishes where a Member State, as a result of new information, has detailed grounds for considering that the use of food or food ingredient endangers human health or environment, that Member State may suspend the use of new genetically modified products on its territory until the final decision is taken at European level. There is introduced the principle of "substantive equivalence" which provides that, in the case of the recognition of products "substantially equivalent", no additional checks are required.

The issue of legal regulation of genetically modified seeds has to be addressed. Thus, the EU legislation provides for the requirements according to which the national authorities have to notify the competent body of the use of seeds in its territory (Council Directive 98/95/EC, 1998). It is also determined that after the verification of the provided information and following the decision to authorisation for the use of seed, the authorities enter it in the Common catalogue of varieties of agricultural plant species (Directive 2001/18/EC, 2001). This procedure is provided to ensure the future unrestricted disposal of genetically modified organisms throughout the European Union. It is established that if the response to the seeds is applied to the food, additional permission is required from the Genetically Modified Food and Feed Regulation. At the level of legal acts, there was a definition regarding the establishment of the principle of "interaction", which is aimed at establishing national strategies and practical steps to implement this aspect (Commission Recommendation of 23 July 2003, 2003). This may suggest the inclusion of the term "interaction" from the standpoint of the concept that explains the presence of farmers growing GMO crops along with those who do not use these organisms. There is also the issue of preservation of the possibility of growing organic raw materials and obtaining organic products. Owners, which use new technologies, should be responsible to those who work without the use of such technologies.

The Convention on Biological Diversity, adopted in June 1992 (the Verkhovna Rada of Ukraine, 1992), sets the foundation for the conservation of biodiversity, the long-term use of its components and the equitable use of profits derived from the exploitation of genetic resources. Each country has sovereign rights, which include the possibility of defining, at the national level, the right to use national resources willingly, when there is no danger to others. All states should cooperate with each other in the field of biodiversity.

Each member state develops a national strategy, as well as a program for the conservation and sustainable use of biodiversity. Such programs and strategies as a whole should include:

- identification of component of biological diversity important for its conservation and sustainable use, as well as processes and categories of activities which have a significant adverse impact on the conservation of biological diversity;

- monitoring of components and processes affecting biodiversity through sampling and other technologies; 
- establishment of a system of protected areas or areas where special measures are taken for conservation of biological diversity;

- protection of ecosystems, natural habitats and the maintenance of viable populations of species in natural surroundings;

- rehabilitation and restoring degraded ecosystems and promoting the recovery of threatened species;

- establishing and maintaining the means to regulate, manage and control the risks related to the use and release of genetically modified organisms resulting from biotechnology which are likely to have adverse environmental impacts;

- prevention of the introduction, control or eradication of those alien species which may pose a threat to ecosystems;

- development of necessary legal base for the protection of threatened species and populations;

- ensuring of measures for the recovery and rehabilitation of threatened species and fro their reintroduction into their natural habitats under appropriate conditions;

- integrating the consideration of the conservation and sustainable use of biological resources into national decision-making process;

- establishing appropriate procedures requiring environmental impact assessment of its proposed projects that are likely to have significant adverse effect on biological diversity; - adoption of national agreements on emergency measures to respond to activity or events cause naturally or otherwise, which present a grave danger to biological diversity;

- ensuring conditions to facilitate access to genetic resources for environmentally sound;

- providing facilitated access and transfer of technologies that are relevant to the conservation and sustainable use of biological diversity and creation of favorable conditions for the use of genetic resources which do not cause a significant damage to the environment;

- ensuring the effective participation in biotechnological research in countries, especially developing countries, with the provision of genetic resources for scientific purposes.

It should also be noted the International Treaty on Plant Genetic Resources for Food and Agriculture 2001 (Verkhovna Rada of Ukraine, 2001), which aims to conserve and sustainably use plant genetic resources for food production and agriculture, and the fair and equitable benefit sharing arising from its use. The fundamental idea behind this act is that plant genetic resources are regarded as an inheritance of mankind, which should be guaranteed by free access without restrictions.

Decision 2004/204/EU Commission (Commission Decision of 23 February 2004 , 2004) formed a detailed agreement on registration operations required for the recording of genetic modification information in organisms regulated by Directive 2001/18/EC of the European Parliament and of the Council of 641/2004 ( Directive 2001/18/EC, 2001).

The provisions of Regulation 65/2004 (Commission Regulation (EC) No $65 / 2004$ of 14 January 2004, 2004) identified the issue of establishing a system for the development and assignment of a unique identifier at different stages of the release of GMOs into the consumption market. Additionally, it should also be taken into account 
the rules of Regulation 1946/2003 (Regulation (EC) No 1946/2003 of the European Parliament and of the Council of 15 July 2003, 2003) as regards the movement of GMOs across borders that are subject to the notification and communication system for transboundary movement. At the regulatory level, there is determined the issue of labelling GMOs, as well as the issue of labelling at the presence of these components in a food and feed (Regulation (EC) No 1830/2003 of the European Parliament and of the Council of 22 September 2003, 2003). It was established the issue of the format of the data on planned growth of GM plants in the environment, but it was not related to the issue of placing them on the market, as in distribution by sale (Commission Decision of 29 September 2003, 2003).

For a comprehensive approach to a particular issue, it is necessary to take into account the legal rules which determine access to environmental information, including the right of free access to environmental information and the provision of free distribution (Directive 2003/4/EC of the European Parliament and of the Council of 28 January 2003). It is also determined the issue of establishing a short list of information, which should be reflected in uncertain forms towards the objectives of planning access to free transfer of GMOs not connected with selling on the marketplace. A short informational format is provided with local locations in the market of products and goods containing GMOs. There is also set out the issue of the management of the planned release of genetically modified organisms into the natural environment and reservations regarding direct, indirect, immediate and later effects on human health arising as a result of release of GMOs into the habitat or distribution to the markets. There are determined the indications about the risk assessment associated with the planned release of GMOs into the environment, as well as the development of further methods to reduce the relevant impacts. There is established the criteria by which can be developed a list of active substances used for the protection of plants that can have unfavourable effects on human health, animals and environment (Council Directive 91/414 / EEC of 15 July 1991, 1991).

The assessment of European legislation defines the issues of regulation regarding liability, namely the availability of a direction to prevent and restore environmental degradation (European Parliament and Council of 21 April 2004, 2004).

It is normatively regulated the issues regarding the revision of the protocol of inspection and testing of existing GM seeds or other plant materials, as well as visualization of the issues of application of technical guidance for sampling, detection of GMOs and components produced by methodical genetic modification (Verkhovna Rada of Ukraine, 2004).

In June 2013, with the aim of securing food safety and consumer rights in the EU it was, a decision was made to make a number of changes to EU legal acts. They concerned the procedure for processing applications for the recognition of GM plants used for food and feed purposes. The basic requirements for the registration of such applications, the availability of general and scientific information, including methods for determining GMOs in products, were formulated. The EU Committee on Sanitary and Phytosanitary Measures reported on 18 June 2013 by the WTO Secretariat on the adoption of the Commission Decision on the Implementation of the EU Regulation No. 503/2013 (Commission Implementing Regulation (EU) No 503/2013 of 3 April 2013, 
2013) aimed at outlining positions on applications for authorization of genetically modified food and feed, as well as amendments to the Commission decision (Commission Regulation (EC) No 641/2004 of 6 April 2004, 2004; Commission Regulation (EC) No 1981/2006 of 22 December 2006, 2006). The mentioned legal norms extend to GM plants that are used for food and feed purposes; food and feed containing or consisting of GM plants; food products produced from GMOs or containing components made from GMOs; feed produced from GM plants. Therefore it is provided the provisions that are mandatory during such economic activities that have a direct impact on climate variability.

Consequently, there is present a considerable level of legal regulation in the sphere of use of genetically modified organisms in the world. However, existing time requirement for changing the economic activity for the purpose of environmental conservation and protection of its components has caused the global community reorientation towards the introduction of organic production or organic management, which is more comprehensive and necessary, and such as requires regulation of legal acts at the national level, since in Ukraine it is a new kind of activity. Such a development should certainly be carried out in the light of existing international legal norms.

\section{Social Relations in the Field of Organic Farming: Legal Regulation for European and National Legislation}

Regulatory framework at the level of the European Union needs to be divided into: general - acts that extend to the European Union in general terms, but the relevant rules grant the right for each Member State to develop at the national level certain legal acts that can, in some cases, contain more stringent requirements than the norms of European law.

The main legal acts on the way of regulating relations in the field of organic activity in the European Union are Regulation (EC) No 834/2007 of 28 June 2007 on organic production and labelling of organic products and repealing Regulations (EEC) No 2092/91, as well as Commission Regulation (EC) No. 889/2008 of 5 September 2008 laying down detailed rules for the implementation of Council Regulation No $834 / 2007$ on organic production, labelling of organic products with regard to organic production, labelling and control.

Certain legal provisions regulate the issues related to the terminological consolidation of organic production and its components, the reasons for such introduction, logos and the process of marking, the purpose and scope of organic production, goals and principles revealing. There are revealed the general and specific principles, to which the latter are distributed depending on the field of application: agricultural production, organic food processing, organic feed processing, production rules, including general rules (prohibition of the use of genetically modified organisms, prohibition of the use of ionizing radiation). Since then, the issues towards activity in the relevant fields are determined, such as for agricultural production - general rules, rules for crop production, rules of seaweed production, rules of livestock production, rules of aquatic animals production, products and substances used in agricultural production, as well as criteria granting of permits for their application, transitional period, feed 
processing including general rules of feed processing, food processing, forks of organic yeast production, criteria for certain products and substances used during processing, flexibility - exceptions to the rules of production, labelling - use of terms related to organic production, mandatory indications, logo for the notification of organic products, specific labelling requirements, control issues - control systems, its observance, supporting documents, measures in case of violations and inconsistencies, exchange of information, trade with third countries - import of the corresponding products, import of products with provision quarterly guarantees, final provisions and rules for the transitional period - free movement of organic products, transmission of information to the Commission, statistical information, the Committee on Organic Production, implementation rules, transitional measures, reporting to the Council, application in general (Council Regulation (EC) No 834/2007) of 28 June 2007, 2007).

The following changes are related to the positions substantiating expediency of the legal regulation of organic production by adopting the appropriate act and its incorporation into the structure of the relevant areas of spreading. In particular, there are introductory provisions; rules of organic production, rules of processing, packaging, transportation and storage of organic products (plant production, livestock production, the origin of animals, the conditions for keeping animals and the practice of farming, feed, disease prevention and veterinary medicine); food products processing; collection, packaging, transportation and storage of products; rules for the transition to organic production; exceptions to the rules of production as the exceptions related to climatic, geographical or structural constraints; related to the absence of relevant agricultural products of organic origin; related to the specific problems of organizing organic livestock breeding; related to force majeure circumstances; database of seed material; marking as the Community logo; specific labelling requirements for feed; other specific labelling requirements; control as minimum control requirements; specific requirements for the control of cultivated and assembled plants and plant products; requirements for the control of animals and livestock products produced in the livestock sector; requirements for the control of enterprises for the preparation of crop and livestock products and food products consisting of plant and livestock products; requirements for controlling the import of plants, crop products, animals, livestock products and food products containing crop and (or) livestock products, animal feeds, fodder and feed materials from third countries; requirements for the control of units involved in the production, preparation, storage and importing organic products and which activities are being transferred to a third party; requirements for control of production units that are involved in the preparation of feed; violation and exchange of information; communication of information to the Commission, transitional and final provisions; Annexes (Commission Regulation (EC) No 889/2008 of 5 September 2008).

In addition, the issues of organic farming are determined by other legal acts among which we should mention: Regulation (EEC) No 2092/91, Regulation (EC) No 882/2004 of the European Parliament and of the Council of 29 April 2004 on official controls performed to ensure the verification of compliance with feed and food law, animal health and animal welfare rules; Commission Regulation (EEC) No 207/93 of 29 January 1993 defying the content of Annex VI to Regulation (EEC) No 2092/91 on organic production of agricultural products and indications referring thereto on 
agricultural products and foodstuffs and laying down detailed rules for implementing the provisions of Article 5 (4) of this Regulation; Commission Regulation (EC) No 1452/2003 of 14 August 2003 maintaining the derogation provided for in Article 6 (3) (a) of Council Regulation (EEC) No 2092/91 with regard to certain species of seeds and vegetative propagating material, and laying down procedural rules and criteria relating to that derogation, as well as Commission Regulation (EC) No 223/2003 of 5 February 2003 concerning the requirements for marking Related to the organic production method feeds, feed and feed materials, which also amended Council Regulation (EEC) № 2092/91.

The Concept of the State Program for the Development of Organic Production in Ukraine of May 18 th 2008 No. 169/2 can be considered as an initial step towards the formation of a further development and adoption of a legislative act in the field of organic production on the territory of Ukraine. Then the regulation of organic farming was based on the State Target Program for the Development of Ukrainian Village for the period until 2015. Subsequently, the State Target Program for the Development of the Agrarian Sector of the Economy for the period up to 2020 (the Cabinet of Ministers of Ukraine, 2015) has been developed.

The Law of Ukraine "On the Production and Circulation of Organic Agricultural Products and Raw Materials", developed in 2013, and amended in 2015, has determined its focus on the legal and economic foundations of production and circulation of organic agricultural products and raw materials and aims at ensuring the proper functioning of the market for organic products and raw materials, as well as to ensure the confidence of consumers in products and raw materials marked as organic (Verkhovna Rada of Ukraine, 2013). However, if we consider its norms, it is possible to determine that not all elements used during the organic production are subject to normative determination, as well as the fact that all the rules of law are general in nature. Certainly, it creates the need for the development of subordinate legal acts, which in its essence creates an accumulation of normative legal acts. Compared with European law, it indicates the need for unification.

As we can see, some changes have taken place in providing normative and legal regulation of organic farming. Such changes consist in the adoption of an updated legislative act, which will come into force on August 2, 2019 (Verkhovna Rada of Ukraine, 2018). However, the new legal act also determines the need for further regulation of the relations in the field of organic farming in the relevant positions.

\section{Conclusions}

After analyzing the European and national regulatory framework, as well as taking into account the fact that any economic activity has a primary impact on the environment, including the climate change, Ukraine faces a number of tasks that should be aimed at ensuring the environment, including in order to preserve, restore its components, protect human, animal and plant health and life. In particular:

1. adopt the Law of Ukraine "On the recognition of Ukraine as a zone free of genetically modified organisms";

2. introduce two areas of activity: clean production (directly for the domestic market) 
and organic farming (both for the domestic market and for export);

3. introduce the definition of "organic farming" as a type of economic (business) activities carried out by business entities, including individuals who have land plots provided for the management of a personal farm or have such holdings in private property in order of inheritance under the law and carry out such activities on their own, and includes certain stages: preparation of land for such production, inspection procedure for planting and breeding resources, introduction of a conversion stage and controlling measures at this period (both for direct and indirect actions in the course of organic farming), the sale of organic products and raw materials, during which the production is carried out (plant growing, livestock, aquaculture, fruit production, including growth of vegetables and fruits, viticulture, beekeeping) and provides a balance between the elements of legal, ecological, economic, socialized systems, both national and international, aimed at the establishment and consolidation of the existence of the environment that is suitable for life as a whole, and its components;

4. "organic farming" - a complex of elements of property and non-property nature, both directly and indirectly used during organic farming;

5. the entity involved in organic farming may be a legal entity or an individual entrepreneur, a united territorial community, a state; individuals who have land plots granted for the purpose of a private peasant farm or received such holdings in private property by inheritance by law to their existing land plots; and the labour participation to determine both direct and indirect;

6. the preparation of land plots for such production should be recognized as a check on all parameters and requirements that are directly established in the Law of Ukraine "On the production and circulation of organic agricultural products and raw materials", taking into account the requirements established by international standards, which further allows the subject to supply and sale of its products to foreign markets without barriers; 7. the subject of clean production should be recognized only individuals who have land plots granted for the conduct of a private peasant farm or have such holdings in private property in the order of inheritance by law to their existing land plots;

8. Individual labour participation during clean production should be determined solely by the implementation of self-management on land plots and obtaining new ones in the order of inheritance by law (in this case, the order of inheritance is recognised not as a procedure for obtaining the inheritance, but as a person's right to inherit, regardless of whether this right is obtained directly by law or by will);

9. preparation of land for clean production should be determined at the discretion of the owner of the land plot or the subject, involved in environmentally sound production, on a royalty-free basis, if the purpose of production of such products is for own needs and for the realization within Ukraine; in the case of willingness to export such surpluses there should be provided a procedure that is typical for entities engaged in organic farming;

10. the procedure for checking planting and breeding resources must be carried out directly at the places of their sale by issuing a confirmatory document regarding their quality and safety, the content of heavy metals, pesticides, radionuclides, chemicals, GMOs, etc. by the relevant authorities; in the case of the duration of such an inspection, to provide appropriate resources to the inspection bodies in advance (taking into account that each equipped implementation site (s) have appropriate laboratories); to provide for 
appropriate inspections by establishing appropriate laboratories with proper supplies; 11. introduction of the conversion stage and control during this period;

12. availability of suitable premises both for direct and indirect actions in the course of organic farming (with the provision of different legal regimes in the direct and indirect actions in organic farming. In particular, direct use of premises should include the use of organic products and raw materials from the purpose of storage, transportation, processing, realization, etc., indirect actions will be considered as those which are related predominantly to the corresponding accessories, premises, etc.);

13. realisation of organic products and raw materials, during which the production is carried out: at the same time, the place of realisation that entails the existence of wholesale markets for organic agricultural products and raw materials and organic stores (or their sectoral departments in ordinary stores);

14. the principles for carrying out clean production and organic farming should be: the principle of determining special sectors among the organic products and raw materials: crop, livestock, aquaculture, fruit production, including growth of vegetables and fruits, vineyards, beekeeping; the principle of ensuring the dynamics of balance between the elements of legal, environmental, economic, socialized systems, both national and international levels; the principle of foreseeing the establishment and consolidation of the life-threatening environment in general, and its components;

15. to introduce in Ukraine a ban on burning forest belts, stubbles, dry weeds, firing beams, slopes, etc.;

16. at the state level (state support) to create Ukrainian breeding and breeding centers aimed at providing landing and breeding material of the subjects of activity;

17. for entities that carry out ecologically clean production, provide preferential treatment for payment of land for a term of 7 years, and for entities that carry out organic farming - up to 3 years;

18. provide free access to European and international markets for manufactured, grown products and raw materials;

19. to enhance attraction of foreign investment and to prohibit foreign persons to receive agricultural lands in the form of lease;

20. to promote the development of cooperative movement in rural areas and settlements;

21. to prohibit the crop-spraying with pesticides at land plots within a radius of $500 \mathrm{~km}$ from a settlement;

22. to develop the Concept of formation of the awareness of the population of Ukraine regarding clean production or organic farming that should be disseminated through the development of appropriate communication at the level of nursery, schools, higher education institutions, as well as among the population through special television programs, radio and other media.

\section{References}

Bezus R.M. (2014). Organizational and economic principles of effective development of organic agricultural production: monograph. Dnipropetrovsk: Lizunov Press, 2014. 380.

Berlach N.A. (2011). Development of the organic direction in agriculture of Ukraine (administrative and legal bases): author's abstract. dis ... doc. lawyer Sciences: special 12.00.07. Kyiv, 2011. 32. 
Gregorich E.G., Beare M.H., McKim U.F., Skjemstad J.O. (2006). Chemical and biological characteristics of physically uncomplexed organic matter. Soil Sci. Soc. Am. J. 2006. 70 (3). 975-985.

Grabak N.H. (2012). The production of environmentally friendly food products is the most promising direction of the agro-industrial complex of Ukraine. Scientific works. Ecology, 2012 194. 206. 126131.

Kirchmann H., Bergstro L., Katterer T., Mattsson L., Gesslein S. (2007). Comparison of Long-Term Organic and Conventional Crop-Livestock Systems on a Previously Nutrient-Depleted Soil in Sweden. Agron. J. 2007. 99. 960-972.

Meniv O.I. (2015). Legal support for the use of GMOs in the cultivation of agricultural products of plant origin in Ukraine and the EU. Thesis for a Candidate Degree in Law. Kharkiv. 2015. 223

Myrick C.A., Tomasso J. R. (2002). Ecological impacts of escaped organisms. Aquaculture and the Environment in the United States. 2002. 225-245.

Overkovskaya T.K. (2017). Legal features of organic production of agricultural products in Ukraine. Enterprise, economy and law. 11/2017. 94-98.

Pavlyuchenko Yu.M. (2015). Legal support of the circulation of environmentally friendly agricultural products. Legal support of economic development and ecological safety of the society: materials of the All-Ukrainian scientific and practical conference devoted to the 50th anniversary of the establishment of the Donetsk National University and the 30th anniversary of the establishment of the Department of Economic Law of Donetsk National University. Vinnytsya. 2015. 278-281.

Piddubnyi O. Y., Piddubna D. S. (2017). Legal system in the context of the formation of environmentally friendly economic management system and the development of biotechnologies. Development and modernization of the legal systems of Eastern Europe: experience of Poland and prospects of Ukraine: Collective monograph. Vol. 3. Lublin: Izdevnieciba "BaltijaPublishing”. 2017. 372. 261351.

Urkevich V.Yu. (2014). On the legal regulation of ecological safety in the production of organic agricultural products. Actual problems of formation and development of the right of ecological safety in Ukraine: materials of the scientific practical round table. Kyiv National Taras Shevchenko University. Chernivtsi, 2014. 49-50.

Cabinet of Ministers of Ukraine (2016). On Approval of the Implementation Concept state policy in the field of change climate for the period up to 2030. Available from: https://www.kmu.gov.ua/ua/npas/249573705 [Accessed 23.04.2019].

Verkhovna Rada of Ukraine (1996). United Nations Framework Convention on Climate Change. The Bulletin of the Verkhouna Rada of Ukraine. 1996. № 50.

Verkhovna Rada of Ukraine (2000). Cartagena Protocol on Biosafety to the Convention on Biological Diversity. Available from: https://zakon.rada.gov.ua/laws/show/995 935 [Accessed 23.04.2019].

Verkhovna Rada of Ukraine (1994). Agreement on the Application of Sanitary and Phytosanitary Measures. Available from: https://zakon.rada.gov.ua/laws/show/981 006 [Accessed 23.04.2019].

Verkhovna Rada of Ukraine (1994). Agreement on Technical Barriers to Trade. Available from: https://zakon.rada.gov.ua/laws/show/981 008 [Accessed 23.04.2019].

SPS Agreement (1994). The WTO Agreement on the Application of Sanitary and Phytosanitary Measures. Available from: https://www.wto.org/english/tratop e/sps e/spsagr e.htm [Accessed 23.04.2019].

Verkhovna Rada of Ukraine (1982). World Charter of Nature. Available from: https://zakon.rada.gov.ua/laws/show/995 453 [Accessed 23.04.2019].

Agendas in the 21st century (1992). Available from: https://www.un.org/ru/documents/decl conv/conventions/agenda21.shtml [Accessed 23.04.2019].

Problems of international legal regulation of GMO treatment (2019). Available from: https://infopedia.su/5x4798.html [Accessed 23.04.2019].

Directive 2001/18/EC (2001). Directive 2001/18/EC of the European Parliament and of the Council of 12 March 2001 on the deliberate release into the environment of genetically modified organisms and repealing Council Directive 90/220/EEC - Commission Declaration Available from: http://eurlex.europa.eu/smartapi/cgi/sga doc?smartapilcelexapilprod!CELEXnumdoc\&lg=EN\&numdoc= 32001L0018\&model=guichett. [Accessed 23.04.2019]. 
Regulation (EC) No 1829/2003 (2003). Regulation (EC) No 1829/2003 of the European Parliament and of the Council of 22 September 2003 on genetically modified food and feed. Available from: https://eur-lex.europa.eu/legal-content/en/ALL/?uri=CELEX\%3A32003R1829 [Accessed 23.04.2019].

A moratorium on the further release of genetically modified organisms (GMOs) (2019). Available from: https://www.ecolex.org/details/literature/a-moratorium-on-the-further-release-of-geneticallymodified-organisms-gmos-mon-091807/ [Accessed 23.04.2019].

Commission Decision of 23 February 2004 (2004). 2004/204/EC: Commission Decision of 23 February 2004 laying down detailed arrangements for the operation of the registers for recording information on genetic modifications in GMOs, provided for in Directive 2001/18/EC of the European Parliament and of the Council. Available from: https://publications.europa.eu/en/publication-detail/-/publication/fcb86b35-7d6e-489a-8b9adb46257a5da2 [Accessed 23.04.2019].

Regulation (EC) No 258/97 (1997). Regulation (EC) No 258/97 of the European Parliament and of the Council of 27 January 1997 concerning novel foods and novel food ingredients. Available from: https://eur-lex.europa.eu/legal-content/en/ALL/?uri=CELEX:31997R0258

[Accessed 23.04.2019].

Council Directive 98/95/EC (1998). Council Directive 98/95/EC of 14 December 1998 amending, in respect of the consolidation of the internal market, genetically modified plant varieties and plant genetic resources, Directives 66/400/EEC, 66/401/EEC, 66/402/EEC, 66/403/EEC, 69/208/EEC, 70/457/EEC and 70/458/EEC on the marketing of beet seed, fodder plant seed, cereal seed, seed potatoes, seed of oil and fibre plants and vegetable seed and on the common catalogue of varieties of agricultural plant species. Available from: https://eur-lex.europa.eu/legalcontent/EN/TXT/?uri=CELEX:31998L0095 [Accessed 23.04.2019].

Directive 2001/18/EC (2001). Directive 2001/18/EC of the European Parliament and of the Council of 12 March 2001 on the deliberate release into the environment of genetically modified organisms and repealing Council Directive 90/220/EEC - Commission Declaration. Available from: https://eurlex.europa.eu/legal-content/en/TXT/?uri=CELEX\%3A32001L0018 [Accessed 23.04.2019].

Commission Recommendation of 23 July 2003 (2003). Commission Recommendation of 23 July 2003 on guidelines for the development of national strategies and best practices to ensure the coexistence of genetically modified crops with conventional and organic farming (notified under document number C(2003) 2624). Available from: https://eur-lex.europa.eu/legalcontent/EN/TXT/?uri=CELEX\%3A32003H0556 [Accessed 23.04.2019].

Verkhovna Rada of Ukraine (1992). Convention on the Protection of Biological Diversity. Available from: https://zakon.rada.gov.ua/laws/show/995 030 [Accessed 23.04.2019].

Verkhovna Rada of Ukraine (2001). International treaty on plant genetic resources for food production and agriculture. Available from: https://zakon.rada.gov.ua/laws/show/995 k92 [Accessed 23.04.2019].

Commission Decision of 23 February 2004 (2004). 2004/204/EC: Commission Decision of 23 February 2004 laying down detailed arrangements for the operation of the registers for recording information on genetic modifications in GMOs, provided for in Directive 2001/18/EC of the European Parliament and of the Counci. Available from: https://eur-lex.europa.eu/legalcontent/EN/ALL/?uri=CELEX:32004D0204 [Accessed 23.04.2019].

Directive 2001/18/EC (2001). Directive 2001/18/EC of the European Parliament and of the Council of 12 March 2001 on the deliberate release into the environment of genetically modified organisms and repealing Council Directive 90/220/EEC - Commission Declaration. Available from: https://eurlex.europa.eu/legal-content/en/TXT/?uri=CELEX\%3A32001L0018 [Accessed 23.04.2019].

Commission Regulation (EC) No 65/2004 of 14 January 2004 (2004). Commission Regulation (EC) No $65 / 2004$ of 14 January 2004 establishing a system for the development and assignment of unique identifiers for genetically modified organisms. Available from: https://eur-lex.europa.eu/legalcontent/EN/ALL/?uri=CELEX\%3A32004R0065 [Accessed 23.04.2019].

Regulation (EC) No 1946/2003 of the European Parliament and of THE Council of 15 July 2003 (2003). Regulation (EC) No 1946/2003 of the European Parliament and of the Council of 15 July 2003 on transboundary movements of genetically modified organisms. Available from: https://eurlex.europa.eu/legal-content/EN/TXT/?uri=celex:32003R1946 [Accessed 23.04.2019]. 
Regulation (EC) No 1830/2003 of the European Parliament and of the Council of 22 September 2003 (2003). Regulation (EC) No 1830/2003 of the European Parliament and of the Council of 22 September 2003 concerning the traceability and labelling of genetically modified organisms and the traceability of food and feed products produced from genetically modified organisms and amending Directive 2001/18/EC. Available from: https://eur-lex.europa.eu/legalcontent/en/ALL/?uri=CELEX\%3A32003R1830 [Accessed 23.04.2019].

Commission Decision of 29 September 2003 (2003). 2003/701/EC: Commission Decision of 29 September 2003 establishing pursuant to Directive 2001/18/EC of the European Parliament and of the Council a format for presenting the results of the deliberate release into the environment of genetically modified higher plants for purposes other than placing on the market. Available from: https://eur-lex.europa.eu/legal-content/EN/TXT/?uri=CELEX\%3A32003D0701 [Accessed 23.04.2019].

Directive 2003/4/EC of the European Parliament and of the Council of 28 January 2003 (2003). Directive 2003/4/EC of the European Parliament and of the Council of 28 January 2003 on public access to environmental information and repealing Council Directive 90/313/EEC. Available from: https://eur-lex.europa.eu/legal-content/en/TXT/?uri=CELEX:32003L0004 23.04.2019].

Council Directive 91/414/EEC of 15 July 1991 (1991). Council Directive 91/414/EEC of 15 July 1991 concerning the placing of plant protection products on the market. Available from: https://eurlex.europa.eu/legal-content/EN/ALL/?uri=celex\%3A31991L0414 [Accessed 23.04.2019].

Directive 2004/35/CE of the European Parliament and of the Council of 21 April 2004 (2004). Directive 2004/35/CE of the European Parliament and of the Council of 21 April 2004 on environmental liability with regard to the prevention and remedying of environmental damage. Available from:

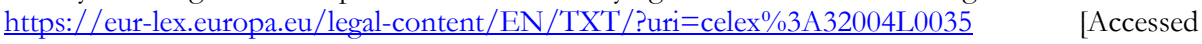
23.04.2019].

Verkhovna Rada of Ukraine (2004). Commission Recommendation 2004/787 / EC on technical guidance for sampling or detection of genetically modified organisms and materials produced from genetically modified organisms as products in the context of Regulation (EC) No 1830/2003 of 4 October 2004. Available from: https://zakon.rada.gov.ua/laws/show/ru/994 998 [Accessed 24.04.2019].

Commission Implementing Regulation (EU) No 503/2013 of 3 April 2013 (2013). Commission Implementing Regulation (EU) No 503/2013 of 3 April 2013 on applications for authorisation of genetically modified food and feed in accordance with Regulation (EC) No 1829/2003 of the European Parliament and of the Council and amending Commission Regulations (EC) No 641/2004 and (EC) No 1981/2006. Available from: https://eur-lex.europa.eu/legalcontent/EN/ALL/?uri=CELEX:32013R0503 [Accessed 24.04.2019].

Commission Regulation (EC) No 641/2004 of 6 April 2004 (2004). Commission Regulation (EC) No 641/2004 of 6 April 2004 on detailed rules for the implementation of Regulation (EC) No 1829/2003 of the European Parliament and of the Council as regards the application for the authorisation of new genetically modified food and feed, the notification of existing products and adventitious or technically unavoidable presence of genetically modified material which has benefited from a favourable risk evaluation. Available from: https://eur-lex.europa.eu/legalcontent/EN/TXT/?uri=uriserv:OJ.L .2004.102.01.0014.01.ENG [Accessed 24.04.2019].

Commission Regulation (EC) No 1981/2006 of 22 December 2006 (2006). Commission Regulation (EC) No 1981/2006 of 22 December 2006 on detailed rules for the implementation of Article 32 of Regulation (EC) No 1829/2003 of the European Parliament and of the Council as regards the Community reference laboratory for genetically modified organisms. Available from: https://eurlex.europa.eu/legal-content/EN/TXT/?uri=CELEX\%3A32006R1981 [Accessed 24.04.2019].

Council Regulation (EC) No 834/2007 of 28 June 2007 (2007). Council Regulation (EC) No 834/2007 of 28 June 2007 on organic production and labelling of organic products and repealing Regulation (EEC) No 2092/91. Available from: https://eur-lex.europa.eu/legalcontent/EN/TXT/?uri $=$ celex\%3A32007R0834 [Accessed 24.04.2019].

Commission Regulation (EC) No 889 / 2008 from September 5, 2008. (2008). Detailed rules for organic production, labeling and control for the implementation of Council Regulation (EC) No.834 / 2007 concerning organic production and labeling of organic products. Available from: 
http://www.organicstandard.com.ua/files/standards/ua/ec/EC Reg 8892008 Implementing Rules UA.pdf [Accessed 24.04.2019].

Cabinet of Ministers of Ukraine (2015). On approval of the State Target Concept programs for the development of the agrarian sector of the economy for the period up to 2020. Available from: https://www.kmu.gov.ua/ua/npas/248907971 [Accessed 24.04.2019].

Verkhovna Rada of Ukraine (2013). On the production and circulation of organic agricultural products and raw materials. Available from: https://zakon.rada.gov.ua/laws/show/425-18 [Accessed 24.04.2019].

Verkhovna Rada of Ukraine (2018). On Basic Principles and Requirements for Organic Production, Turnover and Marking of Organic Products. Available from: https://zakon.rada.gov.ua/laws/show/2496-19 [Accessed 24.04.2019]. 